\title{
Analysis of the influencing factors of voluntary disclosure of internal control deficiencies--empirical test of listed companies in Guangdong
}

\author{
Province \\ Na Liu ${ }^{*}$, Jiaojiao Liu \\ Guangdong University of Foreign Studies South China Business College, \\ Guangzhou,Guangdong \\ *Corresponding author: Na Liu, master,nana4567@126.com
}

\begin{abstract}
This paper selects 2014-2015 annual disclosure of listed companies in Guangdong province listed company internal control evaluation report as samples, analysis of the influencing factors from three aspects of finance, corporate governance, internal and external supervision of internal control deficiencies of the voluntary disclosure of information. The study found that companies were less likely to disclose internal controls if they were issued with standard unqualified opinions; the larger the size of listed companies, the greater the possibility of disclosure of their internal control deficiencies; the greater the proportion of the company's inventory, the higher the likelihood of internal control deficiencies.
\end{abstract}

Key Words: internal control deficiencies; information disclosure; influence factors; corporate governance; financial information; internal and external supervision

\section{Introduction}

The purpose of internal control is to improve the efficiency of operation, optimize the allocation of resources, so that enterprises achieve the intended goal. The enterprises with internal control deficiencies will inevitably bring some economic consequences to the company. Therefore, the listed companies will not voluntarily disclose the internal control deficiencies of the enterprise. Then, if the internal control self-assessment report will reflect the real situation inside the company? The answer is doubtful. What are the factors that make the company reluctant to disclose the company's internal control deficiencies? The disclosure of internal control deficiencies had a significant positive correlation with the earnings quality 
of financial statements through studying of Canadian listed companies (e.g.Gordon Richardson et $a l^{1}$ ). The Chinese scholars found that the quality of auditors employed by companies was negatively related to the disclosure of internal control deficiencies when they made a hypothesis test on auditor quality (e.g.Tian Gaoliang et al $^{2}$ ). Due to different research purposes, different research methods and different sample data, the results of the study may not be unified. Based on this, this paper selects the listed companies in Guangdong Province as the object of study, and analyzes the factors that affect the internal control deficiencies of voluntary disclosure of Listed Companies in Guangdong Province based on the analysis of the current situation of the disclosure of internal control deficiencies, and it also provides a practical reference for the construction of omnibearing and multi-level internal control mechanism in Guangdong province.

\section{Internal control deficiencies disclosure status of listed companies in Guangdong Province}

\subsection{Internal control deficiencies disclosure of the overall situation of listed companies in Guangdong Province}

Guangdong province listed companies are listed on the Shenzhen Stock Exchange, also listed on the Shanghai Stock Exchange. These listed companies disclosure the actual situation of internal control about 2013 and 2014 years in 2014 and 2015 years internal control self-assessment report on internal control. But the two exchanges have different requirements for the disclosure of internal control information. The Shenzhen Stock Exchange does not require all listed companies to disclose self-assessment reports on internal control every year. In order to ensure the sample size and statistical requirements, this paper selects the data before the new policy, that is, the internal control self-assessment report published by in 2014 and 2015 years listed companies in Guangdong Province as the research sample. And according to the following principles of screening samples: excluding delisting in 2013 and 2014 years; after 2014 listed new; and the companies which the internal control self-assessment reports can't be collected. Last, this paper takes 303 companies collected from Sina Financial Website as the research sample, and the overall situation of information disclosure of internal control defects is shown in table 1.

We can see that listed companies in Guangdong province are separately issued internal control self-assessment report from table 1, and there are $70 \%$ listed companies issued appraisal report between 2013 and 2014 years. Compared to the previous visible greatly changed a lot, which shows that the supervision of internal control information disclosure has 
played a certain role in Guangdong province. In Table 1, companies that voluntarily disclose flaws in the company's internal controls are rarely less than $20 \%$, and nearly $70 \%$ of listed companies issued reports clearly stated that the company's internal control without defects. To further understand the persistence and change of disclosure of internal control deficiencies, the disclosures are classified as table 2 .

Table 1-The general situation of internal control deficiencies information disclosure of listed companies in Guangdong Province in 2013 and 2014 years

\begin{tabular}{|c|c|c|c|c|}
\hline \multirow[b]{2}{*}{ disclosure } & \multicolumn{2}{|c|}{2013} & \multicolumn{2}{|c|}{2014} \\
\hline & $\begin{array}{l}\text { the number of } \\
\text { companies }\end{array}$ & ratio & $\begin{array}{l}\text { the number of } \\
\text { companies }\end{array}$ & ratio \\
\hline $\begin{array}{l}\text { the companies which disclose internal control } \\
\text { self-assessment reports }\end{array}$ & 303 & $100.00 \%$ & 303 & $100 \%$ \\
\hline the companies which makes an appraisal report & 208 & $68.65 \%$ & 222 & $73.27 \%$ \\
\hline $\begin{array}{l}\text { the companies which disclose deficiencies in } \\
\text { internal control }\end{array}$ & 44 & $14.52 \%$ & 43 & $14.19 \%$ \\
\hline $\begin{array}{l}\text { the companies which have not disclosed internal } \\
\text { controls }\end{array}$ & 259 & $85.48 \%$ & 260 & $85.81 \%$ \\
\hline $\begin{array}{l}\text { of which: clearly pointed out that internal control } \\
\text { without defects }\end{array}$ & 195 & $64.36 \%$ & 215 & $70.96 \%$ \\
\hline the language is unknown and illegible & 37 & $12.21 \%$ & 22 & $7.26 \%$ \\
\hline refer only to future corrective actions & 27 & $8.91 \%$ & 23 & $7.59 \%$ \\
\hline
\end{tabular}

Table 2-Disclosure of internal control deficiencies of listed companies in guangdong province

\begin{tabular}{l|c|c}
\hline disclosure of internal control deficiencies & the number of Company & ratio \\
\hline companies with no defects in 2013-2014 & 188 & $62.05 \%$ \\
\hline companies that disclose defects in 2013-2014 & 32 & $10.56 \%$ \\
\hline $\begin{array}{l}\text { there was no defect In } 2013 \text { and the company disclosed } \\
\text { defects in } 2014\end{array}$ & 10 & $3.30 \%$ \\
\hline $\begin{array}{l}\text { disclosure flawed in } 2013, \text { there was no defective company } \\
\text { in } 2014\end{array}$ & 12 & $3.96 \%$ \\
\hline
\end{tabular}

As shown in Table 2, 188 of the 303 listed companies have disclosed no internal control deficiencies, accounting for $62.05 \%$ of the total number of companies. There were 32 companies that disclose defects in 2013 and 2014 years, accounting for $10.56 \%$ of the total number of companies. In 2013, there were no defects. In 2014, there were 10 companies with 
defects, accounting for $3.30 \%$ of the total number of companies, and there were 12 companies without defects in 2014, accounting for $3.96 \%$ of the total number of companies. In 2014, fewer than 2 companies were exposed to internal control deficiencies, indicating that the overall situation of internal control is improving.

However, there are still problems in the internal control deficiencies and information disclosure of Listed Companies in Guangdong province. The main performance is the active disclosure of internal control deficiencies is too small, many companies do things carelessly, without the disclosure of internal control deficiencies. Between 2013 and 2014, fewer than 50 companies disclosure internal control deficiencies, accounting for $14 \%$ of the company's total. We can see that the internal control deficiencies often described in the following three situations exist In Table 1: first, clearly pointed out that the company does not exist the defects of internal control; second, the language is unknown, make people cannot recognize the existence of internal control deficiencies; third, do not directly point out that the company internal control deficiencies, only show that next year's internal control plan. This makes it impossible for outsiders to judge the real situation of their internal control deficiencies. No matter what kind of listing, the reason may be that the feedback function of the listed companies to consider the market information transfer will affect the company's share price, so they choose not to disclose the information of the company's internal control deficiencies. Secondly, it may be that the management of listed companies has not yet realized the role of internal control, so they don't have to deal with it. It can be seen from the internal control self-assessment report of 303 listed companies, many companies have the defects of internal control information disclosure is not complete, not standardized, even the contents of internal control self-assessment report of 2013 and 2014 years almost repeat.

\subsection{The specific situation of internal control flaw disclosure of listed companies in Guangdong Province}

Internal control is a process closely dependent on enterprises of various business activities, each company's internal control deficiencies are all embedded and context dependent, and a defect in different industries, different companies bring are not the same. According to the "assessment guidelines" requirements, the listed company should divide the defects of internal control into the major defects, important defects and general defects according to their influence, and requires listed companies to control self-assessment report disclosed internal control deficiencies in internal and cognizance. In view of this, this paper makes a statistical analysis of the degree of internal control deficiencies of Listed Companies in China. The 
listed companies distinguish the severity of internal control deficiencies, as shown in Table 3.

Table 3-The severity of internal control deficiencies in Listed Companies in Guangdong Province

\begin{tabular}{l|c|c|c|c}
\hline \multirow{2}{*}{ disclosure } & \multicolumn{2}{|c|}{2013} & \multicolumn{2}{c}{2014} \\
\cline { 2 - 5 } & $\begin{array}{c}\text { the number } \\
\text { of company }\end{array}$ & ratio & $\begin{array}{c}\text { the number } \\
\text { of company }\end{array}$ & ratio \\
\hline $\begin{array}{l}\text { a company that distinguishes general, important, } \\
\text { and significant internal control deficiencies }\end{array}$ & 5 & $1.65 \%$ & 13 & $4.29 \%$ \\
\hline $\begin{array}{l}\text { acknowledge own existence, internal control, } \\
\text { major defect, company }\end{array}$ & 0 & 0 & 1 & $0.33 \%$ \\
\hline
\end{tabular}

From table 3 we can see that there were only 5 companies pointed out that the internal control deficiencies in the evaluation of Listed Companies in Guangdong province in 2013, and pointed out that belong to the general internal control deficiencies, accounting for $1.65 \%$ of the Sample Firms. There are 13 companies in the internal control evaluation control report in listed company in 2014 in Guangdong Province pointed out the company internal control deficiencies, which accounting for $0.33 \%$ of the Sample Firms are significant deficiencies disclosure. The rest of the Sample Firms in the internal control evaluation report clearly pointed out that the company does not exist significant or significant internal control deficiencies, and indicate the future will continue to improve the internal control, to adapt to the size of the company, business development, changes in the competitive environment. Preliminary results of the statistical analysis in the listed companies of Guangdong Province corporate voluntary disclosure of internal control deficiencies are not many, and the disclosure of internal control deficiencies and internal control weaknesses company is only a few, the disclosure situation of internal control that can reflect the real situation within the company? Doubtful. What are the factors that make the company reluctant to disclose the company's internal control deficiencies? Then, the paper analyzes the influencing factors of the internal control deficiencies of Listed Companies in Guangdong province.

\section{The empirical analysis of the factors affecting internal control deficiencies}

\subsection{Sample selection and sources}

This paper select 2014-2015 years of internal control self-assessment report of Listed Companies in Guangdong Province as the research object, analysis of listed companies internal control deficiencies disclosure factors through empirical research. Sample selection are as follows: (1) excluding the listed companies on the Shanghai stock exchange, and 
selecting the listed companies in Shenzhen listed on the Guangdong stock exchange; (2) eliminate financial enterprises because of the particularity of the financial industry and the CSRC and the stock exchange have different requirements to financial enterprises for the disclosure of internal control information; (3) excluding the listed company in Guangdong province 2013-2014 years of delisting; (4) excluding newly listed companies after 2014; (5) the data of listed companies can't be eliminated. After screening, we finally got the remaining 165 sample enterprises. In this paper, dependent variable of the defects of internal control information comes from the internal control self-assessment report published by the listed company, the influence factor variables (independent variable and control variable) are through the Sina business network to sort out the one hand collected.

\subsection{Research hypothesis}

This paper study the influence factors of the disclosure of internal control deficiencies through summarizing research results of domestic and foreign scholars, and summarize the factors that influence the internal control deficiencies disclosure into three aspects of financial characteristics, corporate governance and external audit.

\subsubsection{Financial aspects}

If the inventory is too large in the normal daily activities in the process for a company, it may cause the possibility of inventory losses is large, and when the inventory cost calculation of the possibility of error is bigger, this will lead to the existence of a risk measurement in terms of enterprise, the higher the possibility of internal control deficiencies (e.g.Tian Yong ${ }^{3}$ ). Therefore, make the following assumptions:

\section{H1: The inventory ratio of listed companies is positively related to the possibility of internal control deficiencies.}

The competition between companies is more and more fierce in the condition of market economy. Business scale and business scope will develop faster and faster, which not only bring some risks to the accounting measurement, but also bring some challenges to the managers of the enterprises in their daily operation. The existing internal controls are easily broken and the possibility of internal control deficiencies is higher(e.g.Cai Congguang $\left.{ }^{4}\right)$. Therefore, make the assumptions.

H2: Listed companies is positively related to the possibility of internal control deficiencies.

\subsubsection{Corporate governance}

The most important role of independent directors is to prevent the damage of the interests of the disadvantaged groups in the enterprise from the large shareholders or managers. It has 
changed the structure of executive decision-making power, and made the board of directors exempt from falling for the managers, so as to achieve the role of supervision and balance. The more perfect the independent director system is, the more perfect the corporate governance structure is, the smaller the possibility of the existence of internal control deficiencies. The number of independent directors and the proportion of all directors can measure the size of independent directors, and the larger the scale, the better supervision and management of enterprises can be provided to improve the construction of internal control. (e.g.Tian Xiaoxue ${ }^{5}$ ) Therefore, make the following assumptions:

H3: The proportion of independent directors in the board of directors is negatively related to the defects of internal control.

A good governance structure can largely avoid the appearance of material misstatement or fraud. If the shareholding ratio of a single shareholder exceeds $30 \%$, it is easy to have an internal agent offside. In many cases, it will lead to the failure of the internal governance structure, and it can't interact with each other and balance each other. (e.g. Liu Yali et al ${ }^{6}$ ) It may lead to material misstatement or fraud. Therefore, make the following assumptions:

H4: The concentration of ownership of the largest shareholder of listed companies is positively related to the internal control deficiencies.

\subsubsection{Internal and external audits}

The annual reports of listed companies should be audited in accordance with relevant regulations. If the certified public accountants believe that the financial statements of listed companies are true, fair and reliable, they will issue unqualified audit opinions. The true, fair and reliable financial statements are based on effective internal control. If the listed company's annual report by the CPA issued a non-standard unqualified audit opinion, the thought problems in legality and fair or other basis for the preparation of the financial statements of listed companies, which also indirectly reflects the defects of internal control of the company(e.g. Wang Yun et $\mathrm{l}^{7}$ ). Therefore, make the following assumptions:

H5: The company has been issued with a standard unqualified opinion and is less likely to disclose deficiencies in internal controls.

The audit committee mainly monitors and provides effective financial reports, controls, identifies and manages the financial risks associated with many factors as an affiliate of the board of directors. If the audit committee meets frequently, it can reflect the degree of activity of the audit committee. It can also show that the agency's monitoring responsibilities to the enterprise are more conducive to in-depth analysis of internal control cost efficiency, so that the opportunities for internal control deficiencies are smaller by improving the system(e.g. Lin 
Bin et $a l^{8}$ ). Therefore, make the following assumptions:

H6: The number of meetings of the audit committee is negatively related to the possibility of internal control deficiencies.

In addition to the above three factors, there are other factors that will affect the occurrence of internal control deficiencies, such as the size of the company. The greater the size of a company, the stronger its strength and the more resources it will put into the voluntary disclosure of its internal control information. For example, there are enough manpower to ensure the separation of powers and responsibilities, proper and reasonable financial operation procedures, and high-level information management systems, which contribute to the improvement of the quality of internal control. At the same time, the company can expand economies of scale and reduce internal control consulting costs. Therefore, make the following assumptions:

H7: The company size is positively related to the disclosure potential of the company's internal control deficiencies.

\subsection{Research variables and model design}

\subsubsection{Research variables}

The paper variables are determined as shown in table 4 according to the research hypothesis in the preceding section. The total variables included dependent variable, independent variable and controlled variable. The dependent variable is the internal control deficiencies disclosure, which is a qualitative variable scalar, and this paper assign values to variables according to internal control rating report Sample Firms in 2014 and 2015 years in the conclusion of the assignment. If company disclosed in the report, the listed company's internal control flaw value is 1 , otherwise is 0 .

\subsubsection{Research model}

On the basis of the previous hypothesis analysis, this paper select internal control defects (ICD) as explanatory variables, the inventory ratio, sales growth rate, the proportion of independent directors, ownership concentration, audit opinions and audit committee meetings as explanatory variables, the scale of the company as the control variables. Logistic multivariate regression model is used for empirical analysis, and the regression model is expressed as follows:

$$
I C D=\alpha_{0}+\alpha_{1} I N V+\alpha_{2} G R T H+\alpha_{3} P I D+\alpha_{4} O S C+\alpha_{5} O P I N+\alpha_{6} N A C+\alpha_{7} S I Z E+\varepsilon
$$

and where $\alpha 0$ is constant, $\alpha 1, \alpha 2, \alpha 3, \alpha 4, \alpha 5, \alpha 6$ and $\alpha 7$ are the independent variable coefficient, $\varepsilon$ is a random error term. 
Table 4-Definitions of influencing factor variables

\begin{tabular}{|c|c|c|c|c|c|c|}
\hline \multicolumn{2}{|l|}{ project } & name of variable & symbol & variable interpretation & $\begin{array}{l}\text { hypoth } \\
\text {-esis }\end{array}$ & $\begin{array}{l}\text { Expect- } \\
\text { ation } \\
\text { symbol }\end{array}$ \\
\hline \multicolumn{2}{|c|}{ dependent variable } & $\begin{array}{l}\text { disclosure of internal } \\
\text { control, deficiencies }\end{array}$ & ICD & disclosed as 1 ; otherwise 0 & & \\
\hline \multirow{6}{*}{$\begin{array}{l}\text { indepen- } \\
\text { dent } \\
\text { variable }\end{array}$} & \multirow[t]{2}{*}{ financial } & inventory ratio & INV & $\begin{array}{c}\text { ratio of inventory to total } \\
\text { assets }\end{array}$ & H1 & + \\
\hline & & sales growth rate & GRTH & sales growth rate & $\mathrm{H} 2$ & + \\
\hline & \multirow[b]{2}{*}{$\begin{array}{l}\text { corporate } \\
\text { governance }\end{array}$} & $\begin{array}{l}\text { proportion of } \\
\text { independent directors }\end{array}$ & PID & $\begin{array}{l}\text { ratio of independent } \\
\text { directors to directors }\end{array}$ & H3 & - \\
\hline & & $\begin{array}{l}\text { ownership } \\
\text { concentration }\end{array}$ & OSC & $\begin{array}{l}\text { the proportion of the } \\
\text { number of shares held by } \\
\text { the largest shareholder in } \\
\text { the total number of shares }\end{array}$ & $\mathrm{H} 4$ & + \\
\hline & \multirow{2}{*}{$\begin{array}{l}\text { internal and } \\
\text { external } \\
\text { supervision }\end{array}$} & audit opinion & OPIN & $\begin{array}{l}\text { the standard views were } 1 \text {; } \\
\text { other observations were } 2\end{array}$ & H5 & + \\
\hline & & $\begin{array}{l}\text { number of meetings of } \\
\text { the audit committee }\end{array}$ & NAC & $\begin{array}{l}\text { total number of meetings } \\
\text { during the year }\end{array}$ & H6 & - \\
\hline \multicolumn{2}{|c|}{ control variable } & company size & SIZE & $\begin{array}{l}\text { the natural logarithm of the } \\
\text { total assets of the company } \\
\text { this year }\end{array}$ & $\mathrm{H} 7$ & + \\
\hline
\end{tabular}

\section{Empirical results and analysis}

\subsection{Descriptive statistics}

According to the above data selection principle, descriptive statistics are made on the selected variables of the 165 listed companies in stock exchange of Shenzhen stock exchange and Guangdong province. Preliminary statistical results are shown in table 5.

From the corporate governance structure, there will be the following preliminary conclusions. (1) The proportion of independent directors is 37.33\%, and it is consistent with the 2001 China issued "on the listed companies to establish the system of guidance" requirements, which are more than 2 people in the independent directors of the listed company, and the proportion of independent directors is not less than 33.33\%. (2) According to the data of the shareholding ratio of the largest shareholder, the minimum shareholding of the largest shareholder is $3.62 \%$, the largest shareholding is $81.85 \%$. After investigation, the proportion of the largest shareholder of a higher proportion of identity is the country. And the 
state-owned enterprises are also undergoing reform at present, and there have been some changes may be two years.

From the index of internal supervision and the number of meetings of the audit committee, it can be seen that the average number of annual audit meetings of the audit committee of Listed Companies in Guangdong is about 4 times. As an important supervisory department of an enterprise, there are not many regular meetings 4 times a year. However, some of the company's audit committee meets at least 1 times a year.

Table 5-Descriptive statistics

\begin{tabular}{l|c|c|c|c}
\hline name & minimum value & maximum value & mean & standard deviation \\
\hline ICD & 0 & 1 & 0.13 & 0.334 \\
\hline INV (\%) & 0 & 92.17 & 17.1765 & 1.7931 \\
\hline GRTH (\%) & -78.38 & 188.02 & 76.3787 & 103.41 \\
\hline PID (\%) & 30.00 & 66.67 & 37.3349 & 5.9559 \\
\hline OSC (\%) & 3.62 & 81.85 & 36.6096 & 15.817 \\
\hline OPIN & 1 & 2 & 1.0273 & 0.1631 \\
\hline NAC (times) & 1 & 12 & 4.1242 & 2.1913 \\
\hline SIZE & 3.94 & 11.96 & 8.0511 & 1.1477 \\
\hline
\end{tabular}

\subsection{Correlation test}

Correlation analysis is a statistical method to analyze the uncertainty relationship between two or more research variables. This paper makes a correlation analysis between dependent variables and independent variables, and the specific results are shown in table 6 .

This paper analyzes the relationship between the defects of internal control, the ratio of inventories to total assets, sales growth rate, independent director proportion, the proportion of the first shareholder, audit opinion, audit committee meetings and the company scale of these research variables in Table 6. The maximum correlation coefficient among the explanatory variables was 23.9\%. According to the study of Thomas and Williams (1991), the correlation coefficient is less than 0.65 , which represents a certain independence between the research variables. The result of correlation analysis does not represent the causal relationship between variables. Because of the independence between the explanatory variables, there is no collinearity between them, and it does not affect the outcome of the regression. 
Table 6-Coefficient of correlation of variables

\begin{tabular}{|c|c|c|c|c|c|c|c|c|c|}
\hline \multicolumn{2}{|c|}{ variable name } & \multirow{2}{*}{$\frac{\text { ICD }}{1}$} & \multirow{2}{*}{$\begin{array}{c}\text { INV } \\
0.099\end{array}$} & \multirow{2}{*}{$\begin{array}{c}\text { GRTH } \\
-0.022\end{array}$} & \multirow{2}{*}{$\begin{array}{c}\text { PID } \\
-0.051 \\
\end{array}$} & \multirow{2}{*}{$\begin{array}{c}\text { OSC } \\
-0.030\end{array}$} & \multirow{2}{*}{$\begin{array}{l}\text { OPIN } \\
0.215^{* *}\end{array}$} & \multirow{2}{*}{$\begin{array}{l}\text { NAC } \\
-0.047 \\
\end{array}$} & \multirow{2}{*}{$\begin{array}{c}\text { SIZE } \\
0.108^{*}\end{array}$} \\
\hline ICD & Pearson Correlation & & & & & & & & \\
\hline & Sig. (2-tailed) & & 0.074 & 0.696 & 0.352 & 0.588 & 0.000 & 0.399 & 0.049 \\
\hline \multirow[t]{2}{*}{ INV } & Pearson Correlation & 0.099 & 1 & -0.046 & -0.009 & 0.042 & -0.032 & -0.084 & 0.061 \\
\hline & Sig. (2-tailed) & 0.074 & & 0.401 & 0.869 & 0.451 & 0.560 & 0.128 & 0.271 \\
\hline \multirow[t]{2}{*}{ GRTH } & Pearson Correlation & -0.022 & -0.046 & 1 & -0.028 & 0.054 & -0.010 & -0.081 & -0.024 \\
\hline & Sig. (2-tailed) & 0.696 & 0.401 & & 0.615 & 0.331 & 0.861 & 0.143 & 0.663 \\
\hline \multirow[t]{2}{*}{ PID } & Pearson Correlation & -0.051 & -0.009 & -0.028 & 1 & $0.110 *$ & -0.082 & 0.103 & 0.077 \\
\hline & Sig. (2-tailed) & 0.352 & 0.869 & 0.615 & & 0.046 & 0.139 & 0.063 & 0.165 \\
\hline \multirow[t]{2}{*}{ OSC } & Pearson Correlation & -0.030 & 0.042 & 0.054 & $0.110 *$ & 1 & -0.045 & 0.042 & 0.071 \\
\hline & Sig. (2-tailed) & 0.588 & 0.451 & 0.331 & 0.046 & & 0.416 & 0.445 & 0.200 \\
\hline \multirow[t]{2}{*}{ OPIN } & Pearson Correlation & $0.215^{* *}$ & -0.032 & -0.010 & -0.082 & -0.045 & 1 & -0.095 & $-0.122 *$ \\
\hline & Sig. (2-tailed) & 0.000 & 0.560 & 0.861 & 0.139 & 0.416 & & 0.086 & 0.027 \\
\hline \multirow[t]{2}{*}{ NAC } & Pearson Correlation & -0.047 & -0.084 & -0.081 & 0.103 & 0.042 & -0.095 & 1 & $0.239^{* *}$ \\
\hline & Sig. (2-tailed) & 0.399 & 0.128 & 0.143 & 0.063 & 0.445 & 0.086 & & 0.000 \\
\hline \multirow[t]{2}{*}{ SIZE } & Pearson Correlation & $0.108^{*}$ & 0.061 & -0.024 & 0.077 & 0.071 & $-0.122^{*}$ & $0.239^{* *}$ & 1 \\
\hline & Sig. (2-tailed) & 0.049 & 0.271 & 0.663 & 0.165 & 0.200 & 0.027 & 0.000 & \\
\hline
\end{tabular}

**. Significant level was $0.01 ;$ * significant level 0.05

\subsection{Regression analysis}

According to the above research model, the regression test was carried out. Because of the internal control defect of the variable, the information disclosure is a non quantitative index, so the Logistic multiple regression model is adopted. The regression results are shown in table 7.

\section{Conclusions and recommendations}

\subsection{Research conclusions}

This paper selects 303 listed companies in Guangdong Province as the research sample, and selects the internal control evaluation report of the company for 2014-2015 years as the object of study. Found that the content of language expression of listed companies of Guangdong Province internal control evaluation report is not clear, leading people can't determine the real situation of the internal control, or directly show that next year's internal control work plan, which is no direct conclusion through collecting, sorting and reading. At the same time, the 
company's internal control reports are same between two years, content repetition rate are higher. Although the content of the disclosure is insufficient, it conforms to the relevant requirements in the form.

This paper selects the Shenzhen Stock Exchange A shares of 165 listed companies in Guangdong Province as the research sample, analysis influence factors of the internal control deficiencies disclosure from three aspects of finance, corporate governance and external supervision. Through regression analysis, the results show that the audit opinion and whether the listed company disclosure is positively related to internal control deficiencies; the scale of the company and whether the listed company disclosure is positively related to internal control deficiencies; inventory ratio and the listed company disclosure of internal control deficiencies are significant positive correlation at the $10 \%$ level.

Table 7- Regression coefficient and significance test

\begin{tabular}{l|c|c|c|c}
\hline variable & $\begin{array}{c}\text { prediction } \\
\text { symbol }\end{array}$ & $\begin{array}{c}\text { estimation } \\
\text { coefficient }\end{array}$ & Wald & Sig \\
\hline INV & + & 0.014 & 2.778 & $0.096^{*}$ \\
\hline GRTH & + & 0.001 & 0.057 & 0.811 \\
\hline PID & - & -0.018 & 0.315 & 0.574 \\
\hline OSC & + & -0.005 & 0.231 & 0.631 \\
\hline OPIN & + & 2.582 & 11.906 & $0.001^{* * *}$ \\
\hline NAC & + & -0.067 & 0.661 & 0.416 \\
\hline SIZE & + & 0.378 & 6.529 & $0.011^{\star *}$ \\
\hline INV & + & 0.014 & 2.778 & $0.096^{*}$ \\
\hline GRTH & + & 0.001 & 0.057 & 0.811 \\
\hline PID & + & -0.018 & 0.315 & 0.574 \\
\hline OSC & + & -0.005 & 0.231 & 0.631 \\
\hline OPIN & + & 0.378 & 11.906 & 0.061 \\
\hline NAC & + & $* .529$ & 0.416 \\
\hline
\end{tabular}

Note: the significant level of $* * *$ is $0.01 ; * * *$ the level of significance is 0.05 ; $*$ stands for 0.1

\subsection{Research proposals}

The lack of internal control in the management leading internal control deficiencies, but the supervisory staff and departments of the independent director and the audit committee do not perform their duties well. How to improve the efficiency of internal and external supervision is a serious reflection of the relevant supervision departments. Research shows that the 
appropriate increase of the number of independent directors, strengthen the supervision of enthusiasm; ensure that the audit committee of the inspection and supervision, and improve supervision efficiency; the establishment of internal control deficiencies disclosure irregularities punishment mechanism; at the same time the good governance, which will help the company to adapt to all kinds of environment and sustainable development.

\subsection{Lack of research}

This paper selects evaluation report of internal control of Listed Companies in Guangdong Province and the content of the disclosure as a source of data acquisition, but this does not guarantee the company internal control deficiencies, while in internal control evaluation report did not disclose that the lack of research sample.

One of the main contents of this paper is the empirical analysis of the internal control deficiencies of listed companies and it needs a large amount of sample data. And in order to ensure the authenticity of the data, each internal control evaluation reports, audit reports and annual reports are reviewed and sorted out. The influencing factors are only 7 variables, namely, stock ratio, sales growth rate, the proportion of independent directors, ownership concentration, audit opinions and the number of meetings of the audit committee, three variables. The index is limited, mainly because some indicators are collected from the listed company website, which will lead to the reduction of the sample data.

\section{Acknowledgements:}

Guangdong provincial philosophy and Social Science （the 13th Five-Year Plan ） Project: internal control information disclosure of listed companies irregularities motivation and early warning mechanism (GD16YGL06).

\section{References:}

1. Lu,H. ,G. Richardson, and S. Salterio. Direct and Indirect Effects of Internal Control Weaknesses on Accrual Quality: Evidence from a Unique Canadian Regulatory Setting. Contemporary Accounting Research,28(2011)675-707.

2.Tian Gaoliang, Qi Baolei, Li Liuchuang. "The Study on the Influencing Factors of Disclosure of Internal Control Deficiencies Based on Financial Reports, Nankai Business Review. 4(2010)134-141.

3.Tian Yong.A Study on the Influencing Factors of Internal Control Deficiencies of Listed Companies in China. Southern finance, 2(2011) .

4.Cai Congguang. Analysis of the Influencing Factors of Information Disclosure of Internal Control Defects. Accounting research, 4(2010) 33-38.

5. Tian Xiaoxue.Analysis of Standards and Factors Affecting Internal Control Deficiencies of Listed Companies in China. Master's thesis. Listing Corporation's Internal Control 
Deficiencies Identified and Analysis of influencing Factors.Liaoning: Shenyang University of Technology, 2012.

6.Liu Yali, Ma Xiaoyan, Hu Zhiying. Disclosure of Internal Control Deficiencies of Listed Companies: A Study Based on Governance Characteristics, auditing and economic research, 3(2011)35-43.

7.Wang Yun, Zhu Zhiming.Analysis of the Factors Affecting the Internal Control Deficiencies Based on 2008 2010 Data of Small and Medium Board Listed Companies, accounting monthly, 11(2011) 10-12.

8.Lin Bin, Rao Jing.Why Voluntary Disclosure of Internal Control Attestation Reports by Listed Companies -- An Empirical Study Based on signaling theory, accounting research, 2(2009)45-52. 